\title{
Research on Causes and Countermeasures of High Surplus of Unemployment Insurance Fund in China
}

\author{
Xiuli Xiang ${ }^{1, a}$ \\ ${ }^{1}$ Zhongnan University of Economics and Law, Wuhan, 430073, China
}

Keywords:Unemployment insurance, Fund surplus, re-employment

\begin{abstract}
Unemployment insurance fund is the material base for the development of unemployment insurance system. At present, the balance of unemployment insurance fund in China has exceeded expectations for many years, and the efficiency of fund utilization is relatively low. This paper discusses the reasons for the high surplus of unemployment insurance fund in our country, and give countermeasures to decease the surplus, including enlarging coverage area, enhancing supply level and promoting employment function to provide some references for the relevant researchers.
\end{abstract}

\section{Current Situation of High Surplus of Unemployment Insurance Fund in China}

Since its establishment in 1986, China's unemployment insurance system has been developing and improving in practice. It has played an important role of "safety net" and "shock absorber" in the continuous reform of China's economic system. However, with the development of society, there are some problems in the operation of unemployment insurance in our country. The most obvious manifestation is the large amount of unemployment insurance funds that have been in balance for several years. It is undoubtedly abnormal for the unemployment insurance system. This paper attempts to analyze the reasons for the continuous emergence of large amounts of unemployment insurance fund balance, and puts forward some solutions. The income, expenditure and balance of the unemployment insurance fund in China from 2007 to 2016 are shown in Table 1.The rise of unemployment insurance balances in China is shown in Figure 1.

Table 1. Income, expenditure and balance of the unemployment insurance fund in China

(Unit: billion Yuan)

\begin{tabular}{|r|r|r|r|}
\hline \multicolumn{1}{l|}{ Year } & Fund income & $\begin{array}{l}\text { Fund } \\
\text { expenditure }\end{array}$ & Fund balance \\
\hline 2007 & 47.2 & 21.8 & 97.9 \\
\hline 2008 & 58.5 & 25.3 & 131.0 \\
\hline 2009 & 58.0 & 36.6 & 152.3 \\
\hline 2010 & 65.0 & 42.3 & 174.9 \\
\hline 2011 & 92.3 & 43.2 & 224.0 \\
\hline 2012 & 113.9 & 45.0 & 292.9 \\
\hline 2013 & 128.9 & 53.1 & 368.5 \\
\hline 2014 & 138.0 & 61.4 & 445.1 \\
\hline 2015 & 136.8 & 73.6 & 508.2 \\
\hline 2016 & 122.9 & 97.6 & 533.3 \\
\hline
\end{tabular}

From the perspectives of annual unemployment insurance fund balances, regional unemployment insurance fund balance and system of mature countries, the unemployment insurance fund accumulated balance highlights a high level of accumulation. According to this trend, we can predict that the level of fund surplus will continue to increase. High accumulation level is contrary to the original intention of establishing unemployment insurance system. In addition, under the current system design, the unemployment insurance fund does not have an investment plan that can maintain value. In the absence of investment and the use of channels, it will only continue to depreciate, while increasing the risk of fund management system. The excessive accumulation of unemployment 
insurance funds is not caused by the low unemployment rate at the moment. Judging from the experiences, the labor market is facing enormous employment pressure. Therefore, it is urgent to improve the unemployment insurance, unemployment benefits and the macro policies of preventing unemployment to alleviate the employment pressure. Therefore, in this context, the accumulation of unemployment insurance funds reflects the plight of the current system. The current situation of unemployment insurance development in our country is that the number of unemployed is increasing and the number of people receiving unemployment insurance is decreasing. The balance of unemployment insurance fund is increasing continuously. People who need unemployment insurance don't get enough money, and unemployment insurance funds face the problem of how to spend the money at the same time.

\section{Unemployment Insurance Fund Balance of Each Year from 2007 to 2016}

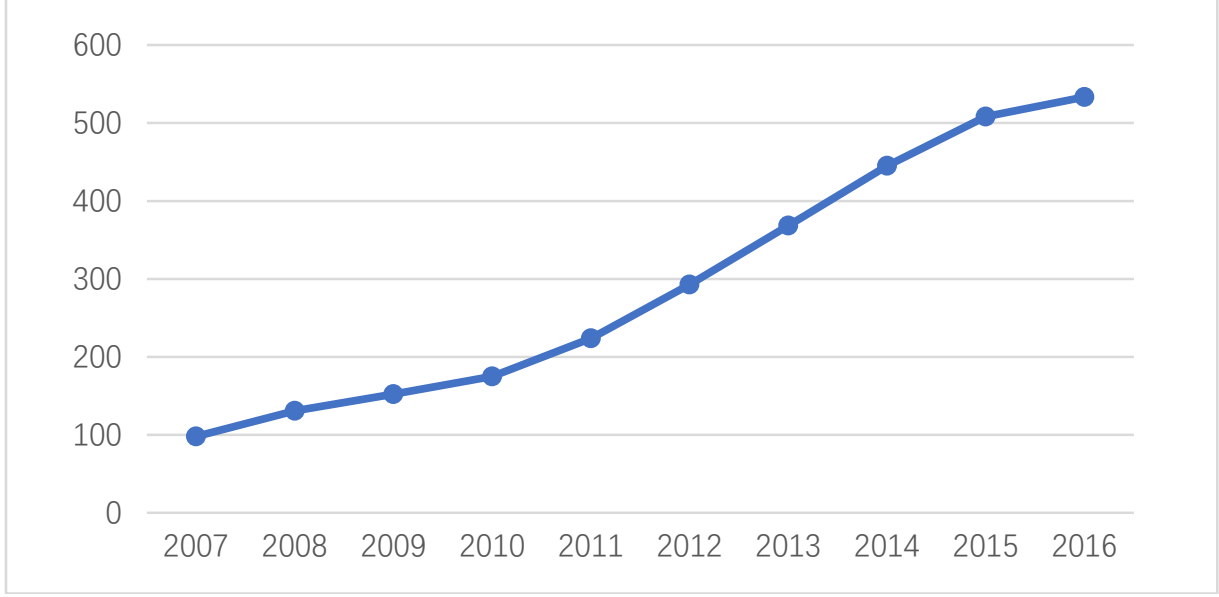

Figure 1. Unemployment Insurance Fund Balance of Each Year from 2007 to 2016

\section{Reasons for High Surplus of Unemployment Insurance Fund in China}

Small Coverage of Jobless People.The unemployment insurance in our country is few. The problem of the narrow coverage of unemployment insurance funds is extremely serious. This problem is related to the current unemployment insurance policy in our country. The relevant laws and regulations of unemployment insurance in China is mainly the "Regulations of the Unemployment Insurance" and "Social Insurance Law". The "Regulations of the Unemployment Insurance" regulates that the unemployment insurance enterprises and institutions in cities and towns shall contract farmers do not pay unemployment insurance for people. At the same time, the "Social Insurance Law" promulgated and implemented in 2015 haven't made clear provisions on the scope of employers and employees. At present, urban workers are the main payment bodies of unemployment insurance, and their unemployment risk is relatively small. Facing the unemployment risk of migrant workers, students and freelancers and other personnel, because of unemployment insurance policy reasons, so that some of these personnel do not have payment eligibility, it cannot get much-needed protection. This is an urgent problem for unemployment insurance in our country. In accordance with the provisions of the unemployment insurance Ordinance, all enterprises and institutions in cities and towns should be insured. But the coverage rate is still low, only about $25 \%$ in recent years. By 2016 , the number of insured persons was about 170 million, but the number of unemployment insurance recipients at the end of the year was decreasing year by year. On average, only about 2 million people receive unemployment insurance benefits each year. Another reason for the excessive balance of unemployment insurance fund in China is the difficulty of obtaining unemployment insurance benefits. This is because unemployment insurance benefits are mandatory. In addition, due to the cumbersome process of receiving and the poor service attitude of some grass-roots staff members, the 
psychological burden of the unemployed has been increased. Their willingness to register unemployment and apply for unemployment insurance benefits is low. This has resulted in some insured participants who have already met relevant rigid indicators have not received insurance benefits.

Little Supply of Unemployment Compensation.The "Regulations of the Unemployment Insurance" regulates that the standard for unemployment insurance benefits is below the local minimum wage and higher than the minimum standard of living for urban residents. At present, the unemployment insurance fund in our country has the problem of mismatch between supply and demand. The unemployment insurance fund benefits fewer people, while the payment level is low. This is because the unemployment insurance system design, which is unable to cope with the huge number of unemployed. It can only meet the minimum living needs, the insured personnel benefit little. With the passage of time, great changes have taken place in China's economic situation, and unemployment insurance did not make big changes. The standard of unemployment insurance payment is relatively low, which makes our unemployment insurance fund spending too little and the surplus more and more. Unemployment insurance in China is a non-family survey based fixed payment, and the level is usually in the interval of $60 \%$ to $80 \%$ of the local minimum wage. From a worldwide perspective, the rate of unemployment insurance substitution in developed countries can reach $50 \%-60 \%$ of the payments of the unemployment of workers in the previous work and $40 \%-50 \%$ in developing countries. Compared with other countries, the substitution rate of unemployment insurance in China is obviously low. In the longitudinal view, the overall rate of unemployment rate in China shows a downward trend. The unemployment insurance payment is low. Due to the complicated application procedures to get low unemployment insurance, it is also very difficult to have the attraction. So, part of the unemployed will not go to apply for unemployment insurance. The situation of the little supply of unemployment compensation should be changed.

Low Function of Promoting Employment. The principle of the unemployment insurance system is transforming from pure unemployment to promoting employment. The unemployment insurance of our country has made some improvements in this area. China's "Regulations of the Unemployment Insurance” regulates the unemployed receive unemployment insurance during the occupation training, occupation introduction subsidies are also included in the unemployment insurance the fund expenditure range, but compared to other developed countries the unemployment insurance system is still far from being. It mainly includes the whole system level and promotes the lack of employment concept. The incompleteness of the existing unemployment insurance legal system restricts the promotion of employment function. The existing employment promotion rules have defects in legislation and technical aspects. Appropriately shorten the unemployment insurance payment period, encourage the unemployed employment as soon as possible. It is the primary goal of China's unemployment insurance benefits to enjoy a longer term. It is not conducive to the promotion of employment, appropriate to shorten the time to enjoy the treatment suggestions. According to the insured contributions of the unemployed, the time limit is not more than eighteen months in an unemployment period. To establish a stable employment subsidy or floating rate mechanism, encourage enterprises to reduce layoffs or absorb the unemployed, reduce staff turnover, establish training subsidies for the enterprise organization, staff training, which can improve the competitive ability of the enterprise, so that employees can also reduce the risk of unemployment, to achieve more stable employment. We can set up emergency reserve funds for unemployment insurance, and provide emergency unemployment benefits for mass unemployment caused by unexpected incidents in some areas. For example, when an earthquake, flood or other disasters occur, workers who are temporarily unable to work, interrupt their income and participate in unemployment insurance should be given an acute unemployment benefit. 


\section{Countermeasures of High Surplus of Unemployment Insurance Fund in China}

Enlarge Coverage Area. The unemployment insurance coverage is narrow. The proportion of beneficiaries is low, and the relatively large liquidity and unemployment risk groups are not covered. In the process of expanding the coverage, we should focus on targeting migrant workers and migrant workers in cities and towns, and reduce the "scissors mouth" so as to give full play to the functions of the unemployment insurance system. At the same time, we should pay attention to the unemployment protection of young unemployed and establish a transitional unemployment protection mechanism to promote their employment at an early date. The objective of unemployment insurance is to stabilize society and promote economic growth, but many people who need unemployment insurance are not eligible for payment and cannot get corresponding protection. If the people who do not have the right to pay the same as other payers have the same protection, they do not accord with the principle of equal rights and obligations. The fundamental purpose of unemployment insurance is to help the unemployed re employment, therefore, whether from the social point of view, or from the personal perspective, employment promotion policy coverage should be expanded. In the current legal system, although not a fundamental change of the situation, it can give full play to the promotion of the public service of unemployment insurance and re-employment function, expanding employment function coverage and strengthening employment function effect.

Increase Supply Level. China's current unemployment rate of substitution is low, the following aspects should be perfected. Consider diversification of the unemployed employment status and meet the different age, income level, family burden diversification demand adjusted. To regulate more stringent unemployment benefits and shorten the period of unemployment benefits, and avoid excessive dependence on the unemployed. A reduced payment mechanism is formulated to prevent the unemployed from creating unemployment traps because of the increase in unemployment rate. The present unemployment insurance payment level is relatively low. This has something to do with the design concept at the beginning of the system establishment. China's unemployment insurance fund is unable to afford more and more unemployed people. It is precisely because of the enormous difficulties raised by the fund. China's unemployment insurance system is difficult to exercise the function of ensuring the level of unemployment consumption, but only with the minimum living security as the goal. More than ten years ago, we developed the policy considering the huge population China actual unemployment and narrowing payment caliber, but today it is still the subject of unemployment who was excluded from the system and in the payment. The rigidity of the system design concept leads to the imbalance between payment and payment. Finally, the system cannot make reasonable arrangements for the use of the fund. The unemployment insurance payment of China's provisions of unemployment insurance is lower than the local minimum wage in accordance with the level. It is higher than the level of the minimum living standard of city residents, determined by the provincial, autonomous regions and municipalities directly under the central government. In many countries, unemployment insurance benefits are paid at an average wage level. In view of this, it is necessary to raise the level of unemployment insurance payment.

Strengthen Promoting Employment. According to the theory of modern unemployment insurance, the basic life of the unemployed is no longer the first goal of unemployment insurance. Fund employment promotion and prevention of unemployment are the key points of the unemployment insurance which should be put into practice. Therefore, we can promote employment and prevent unemployment spending into the unemployment insurance fund expenditure, explore diversified fund channels to give full play to the unemployment insurance fund to promote and protect the function of employment. Specifically, the following points can be referred to. We can consider job subsidies for highly mobile jobs, and provide vocational training for those who are in difficulties. We can set up different types of employment subsidies for college graduates, and expand the function of the unemployment insurance fund to college students. We set up special institutions for college students to enter the post of certain help training. Set up a plan to promote employment activities vacation internship units for college students, providing employment positions such as psychological counseling, job occupation life planning and a series of services to help graduates achieve employment. In addition, the unemployment insurance fund can be also established for 
re-employment assistance and reward system. In the process of reforming the unemployment insurance system in the world, the employment and promotion functions of unemployment insurance can be fully realized through the establishment of employment assistance and reward system.

\section{Conclusion}

They are the important measures to enhance the utilizing efficiency of unemployment insurance to enlarge coverage area, increase supply level and strengthen promoting employment. These measures are conductive to solve the problems of payments imbalances of unemployment insurance fund in China. The issue of the high surplus of unemployment insurance fund will be eased.

\section{References}

[1] Zhao Jing. Unemployment Insurance and Employment Promotion:A Difference-in-Difference Analysis from the View of Fund Expenditure Scope [J]. Economic Issues China, 2014(1): 81-90.

[2] Li Chenguang, QianYuting. On the Causes of High Surplus of Unemployment Insurance Fund in Chinaand the Countermeasures [J]. Journal of Hunan University of Commerce, 2016, 23(6): 22-28.

[3] Wei Chunhui. On the Functional Transformation of China's UnemploymentInsurance System at Present Stage [J]. Journal of Xi'an University of Architecture \& Technology (Social Science Edition), 2017, 36(2): 30-35.

[4] Dong Fang, Zhou Jiangtao, Zhao Junkang. Research on the Function of Promoting Employment of Unemployment Insurance Fund Expenditure:Empirical Tests by Linear Cointegration and Panel Cointegration [J].On Economic Problems, 2015(2): 63-68. 